\title{
Um novo pensamento da comunicação para a mudança social
}

DOI: $10.1590 / 1809-58442019312$

\author{
Cássia Ayres ${ }^{1}$ \\ https://orcid.org/0000-0003-1080-1103
}

${ }^{1}$ (Universidade Lusófona do Porto, Faculdade de Comunicação, Arquitetura, Artes e Tecnologias da Informação, Doutoramento em Estudos em Comunicação para o Desenvolvimento. Porto, Portugal).

TUFTE, T. Communication and Social Change: a citizen perspective. Cambridge: Polity Press, 2017.

A utilização da mídia digital, associada aos movimentos sociais, tem configurado novíssimas possibilidades para a evolução da disciplina e prática da comunicação para o desenvolvimento e mudanças sociais em diversos contextos culturais a romper com estruturas longamente arraigadas em modelos desenvolvimentistas (MANYOZO, 2017, WAISBORD, 2019). Muitas das possibilidades de expressão dos atores sociais são destacadas e criticamente avaliadas na obra "Communication and Social Change: a Citizen Perspective” do professor e pesquisador em Comunicação na área do desenvolvimento e mudanças sociais, Thomas Tufte.

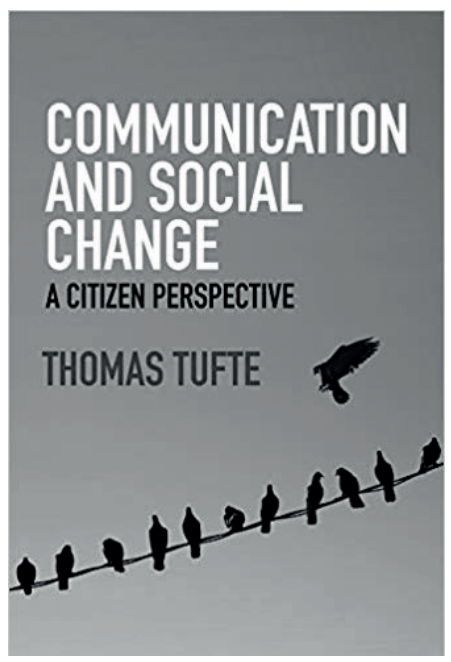

No livro, com tradução para o português em curso e ainda sem data prevista de publicação no Brasil, o autor deseja chamar atenção de acadêmicos, estudantes e profissionais da área “para um novo pensamento social na comunicação para a mudança social” (TUFTE, 2017, p. 1). Tufte (2017) afirma que o livro surge da sua motivação por explorar o campo interdisciplinar que lida com o papel da comunicação em processos de desenvolvimento e mudança social, em uma época em que o interesse pela disciplina nunca foi tão elevado e que, contraditoriamente, as áreas-chave de pesquisa nesta matéria nunca operaram tão em compartimentos (academia, prática institucional, usos pelos cidadãos). É a partir dessa premissa interdisciplinar que Tufte (2017) desafia os leitores a questionarem as formas pelas quais o conhecimento sobre a comunicação para as mudanças sociais possam transpor diversos desses compartimentos ao questionar, por exemplo, sobre novas formas de engajamento com os cidadãos, que podem ser pelas organizações ligadas ao desenvolvimento (ONGs, agências das Nações Unidas e Governos), em sinergias com processos de deliberação política e a ação coletiva digital e nas ruas como um ponto de partida necessário para processos de comunicação com foco no cidadão. 
Na base desse foco, está o pensamento do sociólogo e teórico dos movimentos sociais Alain Touraine e a sua obra “Thinking Differently”, de 2009, que representa um elemento subjacente às ideias de Tufte (2017) e que chama a atenção para um novo pensamento social. Segundo o teórico dinamarquês, tal pensamento parte de uma sociologia que reconhece o poder de ação do indivíduo no coletivo com capacidade de agência, em contraposição aos paradigmas da pós-modernização que fundamentaram a disciplina e as práticas institucionais. É, portanto, a partir desse pensamento social que Tufte (2017) propõe a sua noção de “perspectiva cidadã” na comunicação para a mudança social. A noção é tanto o fio condutor que encadeia logicamente toda a obra, quanto serve de resposta às questões iniciais e complexas que o autor coloca logo no início da obra:

Como acadêmicos e profissionais entendem e conceituam desenvolvimento, agência, participação, uso da mídia e as práticas de comunicação? Qual é o papel da mídia em um processo de transformação social radical? Como trazer os cidadãos para o centro deste processo? E, não menos importante: como transferir estes novos insights de natureza mais espontânea para as práticas institucionais, escalar o êxito e sustentá-lo ao longo do tempo? (TUFTE, 2017, p. 2 - Tradução nossa).

Ao longo de oito capítulos, Tufte (2017) revisa e critica as teorias e modelos que fundamentaram a comunicação para a mudança social, aprofunda casos práticos e examina estudos contemporâneos para embasar, de forma vigorosa, a perspectiva cidadã que defende. Tendo este conceito como fio condutor, o autor conscientiza o leitor para a recuperação dos sentidos ampliados da noção do político, do cultural, do midiático e da participação como parte de um projeto de transformação. Estes sentidos são, para Tufte (2017), os principais desafios para se estabelecer uma base conceitual sobre a qual se pode posicionar as necessidades, os direitos e as responsabilidades dos cidadãos no âmbito da comunicação que, de fato, orientese para a mudança social ao invés de modelos ligados a paradigmas desenvolvimentistas focados na mera transmissão de informação ou na mudança de comportamento.

É nesta via que Thomas Tufte explora a fundo os movimentos sociais contemporâneos que foram orquestrados nas redes digitais e que ganharam as ruas no pós-Primavera Árabe. Ao analisá-los conceitualmente, o autor persiste em seu objetivo interdisciplinar, buscando perceber como as diversas teorias centradas nos movimentos sociais, somadas às práticas diárias dos ativistas destes movimentos, são capazes de produzir novos insights práticos e também de revelar desafios comuns para a comunicação para a mudança social feita institucionalmente.

O Brasil, país com o qual Thomas Tufte sempre manteve uma relação muito próxima ${ }^{1}$, é um ponto à parte, pois está presente em toda a obra. O contexto brasileiro é visível a

1 Tufte tem mantido uma relação próxima com o Brasil desde que morou no Rio Grande do Sul no início dos anos 1980. O pesquisador escreveu suas teses de graduação, mestrado, doutorado e pós-doutorado sobre questões de desenvolvimento brasileiro e, atualmente, está desenvolvendo um novo projeto de pesquisa sobre desenvolvimento da sociedade civil e comunicação participativa no Brasil. 
partir do legado do pedagogo Paulo Freire na comunicação para o desenvolvimento que Tufte cita frequentemente como alicerce teórico da sua perspectiva centrada no cidadão. Em convergência com as novas expressões digitais do Brasil, Tufte (2017) debruça-se, com frequência, sobre os mais recentes movimentos sociais de junho de 2013. Destes movimentos, destacam-se o V de Vinagre (pela redução do aumento das passagens de ônibus iniciado em São Paulo e com repercussão em diversas outras capitais), os protestos contra a realização da Copa do Mundo em 2014 (vulgarmente conhecidos como o Não vai ter Copa) e o trabalho do coletivo de comunicação Mídia Ninja (que surge durante os protestos referidos e que se afirmou como uma nova expressão do jornalismo alternativo).

O leitor mais acostumado com um texto expositivo e monológico da maioria dos livros acadêmicos irá surpreender-se com o estilo de Thomas Tufte, bem mais dialógico pelas inúmeras questões que convidam o leitor à reflexão. Seja pelo pertinente conteúdo que traz, seja pelo formato convidativo como o autor o apresenta, a obra de Tufte (2017) é uma leitura imprescindível a estudantes e profissionais das ciências sociais e humanas ligados à participação, empoderamento e mudanças sociais.

\section{Referências}

MANYOZO, L. Communicating development with communities. Routledge, 2017.

TUFTE, T. Communication and Social Change: a citizen perspective. Cambridge: Polity Press, 2017.

WAISBORD, S. Communication: A Post-Discipline. John Wiley \& Sons, 2019.

\section{Cássia Ayres}

Doutoranda do curso de Estudos em Comunicação para o Desenvolvimento na Universidade Lusófona do Porto e pesquisadora do Centro de Investigação da Universidade Lusófona do Porto - (CICANT) em temas associados à comunicação para o desenvolvimento, ativismo social e digital, participação política e mudanças sociais em países em desenvolvimento. E-mail: cassia.ayres2@gmail.com.

Recebido em: 01.07.2019 Aprovado em: 01.08.2019

Este artigo é publicado em acesso aberto (Open Access) sob a licença Creative Commons Attribution Non-Commercial (CC-BY-NC), que permite uso, distribuição e reprodução em qualquer meio, sem restrições, desde que sem fins comerciais e que o trabalho original seja corretamente citado.

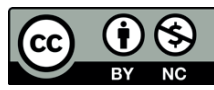

